\title{
Study Impact of Integration Between Cover Crop and Weed Control Treatments on Weeds and Improved Sugarcane Productivety
}

\author{
Gad, A.A. ${ }^{2}$; M.A. Ali ${ }^{1}$; E.A. Abd El-Lattief ${ }^{1}$ and M.S. Mekky ${ }^{2}$
}

${ }^{1}$ Agronomy Department, Faculty of Agriculture, South Valley University, Egypt

${ }^{2}$ Weed Research Laboratory, FCR, Agric. Res. Center, Giza-Egypt

Received on: $15 / 11 / 2018$

Accepted for publication on: 22/11/2018

Abstract

A filed experiment was carried out at Al-Mattana Agricultural Research station, Agricultural Research Center, Luxor Governorate during 2015/16 and 2016/17 seasons, to study the effect of intercropping soybean (cover crop) with sugarcane crop, sole sugarcane and weed control treatments i.e. (Stomp at 1.75 l/f. hand hoeing twice at 25 and 45 days after planting and unweeded check) as the integrated weed control on fresh and dry weight of weeds $\left(\mathrm{g} / \mathrm{m}^{2}\right)$ and yield of primary crop (sugarcane) and secondary crop (soybean) which intercropping with sugarcane in natural infested soil by weeds. The experiment was laid out in randomized complete block design (RCBD) under split plot arrogant with four replication, intercropping treatments was put in the main plots and weed control treatment in split plots with four replications for each treatment.

The infestation rates in field experiments were 8.79 ton/fed broad-leaved weeds, 8.66 ton/fed grassy and 17.45 ton/fed total weeds in 2015/16 season and 11.86 ton/fed broad-leaved weeds, 7.05 ton/fed grassy weeds and 18.91 ton/fed total weeds in $2016 / 17$ season. Intercropping soybean with sugarcane reduced fresh weight of total weeds at 75 days after planting about 56 to $59 \%$, as well as improvement sugarcane yield attributes traits such as stalk length, diameter, number of stalk/fed and number of internodes/stalk which reflected on cane yield and sugar yield ton/fed. in both seasons, compared to sole sugarcane.

Weed control by hand hoeing twice and Stomp at the rate of $1.75 \mathrm{l} / \mathrm{f}$. reduced fresh weight of total weeds at 75 days after planting by about 81 to $85 \%$ and 69 to $72 \%$, respectively, compared to unweeded check, and increased stalks and top yield (ton/fed.) of sugarcane than unweeded check in average of both seasons.

The interaction effect between intercropping soybean with sugarcane and weed control treatments decreased were significantly fresh weight of total weeds, improved sugarcane yield attributes traits and cane and top yield (ton/fed.) of sugarcane compared to the sole sugarcane and without weed control. Intercropping soybean and without weed control treatments reduced fresh weight of total weeds at 75 after day planting by 71.71 and $70.01 \%$ than sole sugarcane and without weed control treatments. Hand hoeing twice reduced fresh weight total weeds at 75 after day planting by 93.78 and $87.91 \%$ with sole sugarcane and by 87.78 and $87.66 \%$ with intercropping soybean in $2015 / 16$ and 2016/17 seasons, respectively, compared to sole sugarcane and without weed control. Using Stomp at $1.75 \mathrm{1} / \mathrm{fed}$ reduced fresh weight of total weeds at 75 after day planting by 85.24 and $84.35 \%$ under intercropping soybean and by 75.45 and $80.42 \%$ under sole sugarcane in 2015/16 and 2016/17 seasons, respectively, compared to sole sugarcane and without weed control.

From this investigate cane be recommended to sowing sugarcane fields intercropping with soybean legume crop as the animal feeding and weed control by hand hoeing twice or Stomp at the rate $1.75 \mathrm{l} /$ fed to overcome on weeds problems and increased sugarcane productivity as well as increased gross income by productivity the second crops (soybean as a forage crop).

Keywords: Sugarcane, soybean, weed control, cane yield and juice quality. 


\section{Introduction}

The sugar industry plays a significant economy role in Egypt. Sugarcane is one of the oldest cultivated crops by man. Sugarcane is cultivated on about 335 thousand fedane, with an average yield of 38.0 ton/fed. 2016 and mainly cultivated in Upper Egypt (Menia, Sohag, Qena, Luxor and Aswan). However, the current sugar production provides only $60 \%$ of the annual demand for domestic consumption. Thus, there is a high to need increase the production of sugarcane in order to have a reliable supply of sugar in the country. However, the yield of sugarcane is limited by many factors among which weeds are the major constraints of sugarcane production. The competition caused by weeds is a major factor limiting sugarcane production; this crop presents a low competitive ability at the beginning of its cycle due to its slow initial growth and wide spacing between planting rows. Without weed control, the yield may be reduced by $20-90 \%$, depending on the species and density of weeds, (Griffin 2009, Kuva et al., 2003 and McIntyre 1991). Weed competition from May until harvest was eliminated, red morningglory (Ipomoea coccinea L.) control is critical to prevent climbing and wrapping of sugarcane plants, red morningglory competition reduced cane and sugar yields around 27\% (Griffin and Jones, 2004).

To reduce the amount of herbicides used for weed control in sugarcane, both for economical and environmental reasons, an Integrated Weed Management (IWM) involving a combination of cultural, mechanical, biological, genetic, and chemical methods has become a priority (Swanton and Weise 1991). To achieve this, there is a need for better understanding of sugarcane-weed interactions and identification of the critical periods of weed competition with respect to crop growth, the dry matter accumula- tion by the weed community increased during the entire period, weed interference in sugarcane caused $40 \%$ of yield loss, the critical period for weed control was between 74 and 127 days after planting and 75 DAP may be reduce shoot borer populations, (Srikanth et al. 2002 and Kuva et al. 2003). Duration of critical periods of weed interference on $5 \%$ acceptable cane yield loss ranged from 2.5 to 14 weeks after planting, (Yirefu et al. 2013). The intercropping of soybean and/or other legumes crop on the side ridge with sugarcane and/or other main crops, recorded the lower total of weed population, (Mekky (1998), Sarhan et al. 2003, Mahendranan and Kulanthaivelu 2003 and Mekky et al. 2007), the cowpea leaf, fresh and dry weight yields (50 DAP), 19.4 and 2.5 $\mathrm{t} /$ ha, respectively, decreased to 17.0 and $2.4 \mathrm{t} / \mathrm{ha}$ (100 DAP). Although the sugarcane total recoverable sucrose $(\mathrm{kg} / \mathrm{t})$ was greater with the kenaf cover-crop treatment at 50 DAP $(120 \mathrm{~kg} / \mathrm{t})$ compared to the cowpea treatment at 50 DAP (111 $\mathrm{kg} / \mathrm{t}$ ) and the cowpea 100 DAP with the residue incorporated $(112 \mathrm{~kg} / \mathrm{ha})$, none of the follow plant system (FPS) crop treatments were significantly better or worse than the control (no cover crop). The average values for the sugarcane production factors across all treatments were 95,700 stalks/ha millable stalks, 112 tons/ha sugarcane yield, $114 \mathrm{~kg} / \mathrm{t}$ as sugar yield per ton of sugarcane or $12,841 \mathrm{~kg} / \mathrm{ha}$ as sugar yield per hectare. The results demonstrate the potential use of these alternative cover crops during the fallow period prior to planting sugarcane without adversely affecting the plant cane yields. However, weeds are the major a biotic constraint and so far, herbicides are the only answer to deal with this problem. Over reliance of herbicide use showed its consequence in terms of environmental pollution, weed shift and herbicide resistance development in weeds. The integrated weed 
management technologies involving the time tested cultural practices, competitive crop cultivars, mulches, cover crops, intercrops with allelopathic potential, crop diversification, planting geometry, efficient nutrient, water management, etc, along with limited and site-specific herbicide application, that helps in managing weeds through retention of crop, (Singh et al., 2014). Higher yield of sugarcane, sugar contents and sugar yield were recorded by weed control with Gesapex combi at $2.5 \mathrm{~kg} / \mathrm{ha}$ or hand hoeing (Bahadar et al., 2004). The high nitrogen requirement of sugarcane is problematic for small scale farmers in Upper Egypt due to the high cost and scarcity of fertilizer. Producing legume crops intercropping with sugarcane during the same period may alleviate the problem. Soybean was a better intercropping option. This intercropping system with the advantage of shorter duration which did not coincide with the active tiller stage as most of the long duration has and by virtue of them being leguminous crops with the ability to fix atmospheric nitrogen which compliment and supplement sugarcane crop by enhancing its growth and productivity. The additional filled gap of the green feed production in summer season, which, income released by these crops in addition to sugarcane yield and economic feasibility (Singh et al., 2014; Webber, 2016 and El-Shafai et al., 2010) indicated that practicing hand hoeing three times 25, 45 and 65 DAP to get rid of weeds associated to sugarcane plants resulted in the highest values, getting the highest cane and sugar yields/fed economic evaluation and gave the highest values of net income and profitability\%.

Fakkar et al., 2017 Showed that the most effective treatment in eliminating both grassy and broadleaved weeds was hand hoeing three times and increase in stalk height, number of millable canes, cane and sugar yields/fed.
This investigation was conducted to study the integration between weed control and cover crops on efficiency of the aforementioned herbicides under sowing soy bean as a cover crop with sugarcane compared with using herbicides alone and sole sugarcane crop for weed control and sugarcane production.

\section{Materials and Methods}

A filed experiment was conducted at Al-Mattana Agricultural Research station, Agricultural Research Center, Luxor Governorate (Upper Egypt) in both successive growing seasons of $2015 / 16$ and $2016 / 17$ to investigate the integration between cover crop and weed control treatments on weeds and sugarcane productivity in both seasons. The preceding winter crop was wheat (Triticum SP L.) in both seasons, the experiment was laid out in design randomized complete block, using split-plots design with four replication and the treatments categories were:

\section{A: Main plots: Intercropping system.}

$A_{1}$ - Soybean intercropped with sugarcane.

$\mathrm{A}_{2}$-Sole sugarcanes.

B: Sub plots: Weed control treatments.

$\mathrm{B}_{1}$ - Stomp 50\% EC (Pendimethalin): sprayed as pre-emergence at the rate of $1.75 \mathrm{l} / \mathrm{fed}$. for control broad leaved and grassy weeds.

$\mathrm{B}_{2}-$ Hand hoeing twice at 25 and 45 days after planting (DAP).

$\mathrm{B}_{3}$ - Unweeded check.

Herbicides treatments were sprayed with a Knapsack sprayer equipped with one nozzle boom and the water volume was $2001 /$ fed.

Cane planting (main crop) variety $\mathrm{C}_{9}$ (twenty five $\mathrm{cm}$. long and three budded sets of cutting) was planted in each furrows, each sub-plot contained 5 furrows, $7 \mathrm{~m}$ long and $100 \mathrm{~cm}$ apart, the sub- plot area was $35 \mathrm{~m}^{2}$ by dry methods of sugarcane planting. Soybean was planting in both ridges of row in double 
seeds per hill spaced $20 \mathrm{~cm}$. apart at seeding rate 20 of $\mathrm{kg} / \mathrm{fed}$. The planting dates were on $30^{\text {th }}$ and $29^{\text {th }}$ April in the first and second seasons, respectively, for each crops and harvested of sugar cane in $15^{\text {th }}$ and $13^{\text {th }}$ April in the first and second seasons, respectively.

Common, chemical names and mode of actions of herbicide used in the experimental plots.

- Pendimethalin, Group: dinitroaniline No: $\mathrm{CH}_{3}-\mathrm{NHCHCCH} 2 \mathrm{OH}_{3}$
- Chemical name: $N$-(1-ethylpropyl)3,4-dimethyl-2,6-dinitrobenzenamine

- Mode of action: Microtubule assembly inhibition and inhibition roots growth. Selective herbicide can be absorbed by roots and leaves. Affected plants die shortly after germination or following emergence from the soil.

The mechanical and chemical analysis of the experimental soil was presented in Table 1 according to Jackson (1958).

- Common ammionendimethalin

Table 1. The properties of the soil analysis (mechanical and chemical properties of the experimental soil.

\begin{tabular}{|c|c|c|c|}
\hline \multicolumn{2}{|c|}{ Seasons } & $2015 / 2016$ & 2016/2017 \\
\hline \multirow{3}{*}{ Physical analysis } & Sand \% & 11.68 & 10.88 \\
\hline & Silt $\%$ & 21.00 & 19.00 \\
\hline & Clay\% & 67.32 & 70.12 \\
\hline \multicolumn{2}{|c|}{ Soil texture } & Sandy loam & Clay loam \\
\hline \multirow{13}{*}{ Chemical analysis } & Organic matter (\%) & 0.6 & 0.7 \\
\hline & Total N (\%) & 18 & 19 \\
\hline & \multicolumn{3}{|c|}{ Soluble ions (meg/100g soil $(1: 5))$} \\
\hline & $\mathrm{CO}_{3}^{-}$ & 0.1 & 0.1 \\
\hline & $\mathrm{HCO}_{3}^{-}$ & 0.69 & 0.56 \\
\hline & $\mathrm{Cl}^{-}$ & 0.42 & 0.23 \\
\hline & $\mathrm{SO}_{4}{ }^{=}$ & 0.37 & 0.27 \\
\hline & $\mathrm{Ca}^{++}$ & 0.50 & 0.32 \\
\hline & $\mathbf{M g}^{++}$ & 0.30 & 0.19 \\
\hline & $\mathrm{Na}^{+}$ & 8.00 & 11.00 \\
\hline & $\mathbf{K}^{+}$ & 0.08 & 0.09 \\
\hline & EC(ds/m)(1:5) & 0.23 & 0.22 \\
\hline & pH(1:1) & 7.60 & 7.90 \\
\hline
\end{tabular}

Phosphorus fertilizer was applied as calcium super phosphate $\left(15.5 \% \quad \mathrm{P}_{2} \mathrm{O}_{5}\right)$ during soil preparation at the rate of $150 \mathrm{~kg} /$ fed., Nitrogen fertilizers were applied in the form of urea $(46.5 \% \mathrm{~N})$ in three portions $(1 / 5)$ after planting and before first irrigation, $(2 / 5)$ before second irrigation $(2 / 5)$ before the third irrigation. The other normal agricultural practices of sugar cane growing were done as recommended.

\section{Data recorded:}

The following data was recorded during the growing seasons of experiments as follow:

\section{A - Weed survey}

Weeds were hand pulled randomly from square meter of each sup plot after 75 days from planting to estimate the fresh weights of annual broad-leaved, grassy and their total weeds as $\left(\mathrm{g} / \mathrm{m}^{2}\right)$.

B - Soybean green forage yield (secondary crop ton/fed):

Soybean plants were mowing after 60 days from planting for each sub-plot and weighed (kg/plot) to determined forage green yield as (ton/fed.)

C- Sugarcane (Main crop) yield and yield attributes: 
$\mathrm{C}_{1}$ - Stalk length $(\mathrm{cm})$ : Ten stalks were measured from ground level up to the top visible dewlap (T.V.D.) after 8 month from planting.

$\mathrm{C}_{2}$ - Number of millable cane was recorded by counting the number of mature stalks in the two center furrows for each sup-plot then estimated number of millable cane/fed.

$\mathrm{C}_{3}$ - Stalk diameter $(\mathrm{cm})$ : Ten mother stalks was taken randomly from each sup - plot at harvested to estimated stalk diameter as $(\mathrm{cm})$.

$\mathrm{C}_{4}$-Number of internodes/stalk.

$\mathrm{C}_{5}$ - Net cane yield (ton/fed): Clean cane yield of the each experimental unit was weighed and estimated by tons of millable cane per fed.

$\mathrm{C}_{6}$ - Net top yield (ton/fed): Clean top yield of the all plot was weighed and estimated by tons of mill able cane per fed.

$\mathrm{C}_{7}$-Theoritical sugar yield (ton/fed.): It was determined by the equation outlined an by Yadav and Sharma (1980).

Suger yield $($ tons/fed) $=$ cane yield (tons/fed) *[[sucrose -0.4(Brix - sucrose)]*0.73]

\section{Statistical analysis}

Data is subjected to the proper statistical analysis of variance of a randomized complete block design in one split plot system as out lined by Steel and Torre (1980). Least significant difference (LSD) at 5\% level of the probability was used to compere treatment means.

\section{Results and Discussion}

Weed survey in these field experiments showed that Portulaca oleraceae, (Purslane); Euphoria geniculata, (Spurge) Xanthium strumar- ium, (Cocklebur); Amaranthus retroflexus, A. hybried, (Redroot pig weed) Ipomeas pp., (Morningglory) and Corchorus oltorius, (Nalta jute) as the dominant broad-leaved weeds and Echinochlae colonum (Jungle rice) and Brachiaria repuns, (Signal grass) as grassy leaved weeds in both seasons.

\section{A - Effect of intercropping and weed control treatments on:}

1-Fresh weight of weeds at 75 days after planting $\left(\mathrm{g} / \mathrm{m}^{2}\right)$ :

Data in Table 1 and Fig. 1 reveal that the intercropping soybean with sugar can in the same time can be reduced fresh weight broad-leaved at 75 DAP by 57.8 and $55.6 \%$, grassy weeds by 60.2 and $56.6 \%$ and total weeds by 59.26 and $55.97 \%$ in 2015 and 2016 seasons, respectively, compared to sugarcane sole. These results due to mowing soybean and weeds in intercropping treatments and less available elements for weed due to increased number of plants than sowing sugarcane sole. These results are in agreement with those mentioned by El-Shafai et al. (2010) and Webber (2016).

Table 1 and Fig. 1 Mentioned that each hand hoeing twice and Stomp reduced significantly fresh weight of broad-leaved, grassy weeds and total weeds $\mathrm{g} / \mathrm{m}^{2}$ in both seasons, compared to unweeded check. Hand hoeing twice and Stomp caused reduction broad-leaved by 85.91 and $80.36 \%$ and 71.84 and $77.33 \%$, grassy weeds by 84.88 and $82.7 \%$ and 65.88 and $68.08 \%$ and total weeds by 85.4 and $81.21 \%$ and 68.87 and $72.94 \%$ in $2015 / 16$ and $2016 / 17$ seasons, respectively, compared to unweeded check. These results due to 
pulling weeds plant by hand hoeing or killing weeds by Stomp herbicide.

These results are in harmony with those obtained by (Mekky et al.,
1998; Sarhan et al., 2003 and Mekky et al., 2007).

Table 2. Effect of intercropping and weed control treatments on fresh weight $\left(\mathrm{g} / \mathrm{m}^{2}\right)$ of weeds at 75 DAP in $2015 / 16$ and $2016 / 17$ seasons

\begin{tabular}{|c|c|c|c|c|c|c|c|c|}
\hline \multirow{3}{*}{ Treats } & \multicolumn{4}{|c|}{ Fresh weight $\left(\mathrm{g} / \mathrm{m}^{2}\right)$} & \multicolumn{4}{|c|}{ Fresh weight of total weeds $\left(\mathrm{g} / \mathrm{m}^{2}\right)$} \\
\hline & \multicolumn{2}{|c|}{$\begin{array}{l}\text { broad-leaved } \\
\text { weeds }\end{array}$} & \multicolumn{2}{|c|}{ grassy-leaved weeds } & \multirow{2}{*}{$\begin{array}{c}\begin{array}{c}\text { Weight } \\
\text { (g) }\end{array} \\
2015 / 16\end{array}$} & \multirow{2}{*}{$\begin{array}{c}\begin{array}{c}\text { Reduction } \\
\%\end{array} \\
2016 / 17 \\
\end{array}$} & \multirow{2}{*}{\begin{tabular}{|c|}
$\begin{array}{c}\text { Weight } \\
(\mathrm{g})\end{array}$ \\
$2015 / 16$ \\
\end{tabular}} & \multirow{2}{*}{$\begin{array}{c}\begin{array}{c}\text { Reduction } \\
\%\end{array} \\
2016 / 17 \\
\end{array}$} \\
\hline & 2015/16 & 2016/17 & 2015/16 & 2016/17 & & & & \\
\hline \multicolumn{9}{|c|}{ Intercropping system treatment } \\
\hline Intercropping & 370.65 & 550.33 & 367.26 & 319.96 & 737.91 & 59.26 & 870.29 & 55.97 \\
\hline Sugar cane sole & 878.4 & 1238.63 & 922.84 & 737.99 & 1801.24 & 0.00 & 1976.62 & 0.00 \\
\hline F test. at $5 \%$ & $*$ & $*$ & $*$ & $*$ & $*$ & - & $*$ & - \\
\hline \multicolumn{9}{|c|}{ Weed control treatments } \\
\hline Stomp & 370.92 & 452.50 & 445.88 & 339.69 & 816.81 & 68.87 & 792.19 & 72.94 \\
\hline Hand hoeing twice & 185.60 & 366.06 & 197.57 & 183.99 & 383.17 & 85.40 & 550.05 & 81.21 \\
\hline Unweeded check & 1317.06 & 1863.90 & 1306.69 & 1063.22 & 2623.74 & 0.00 & 2927.12 & 0.00 \\
\hline L. S. D. at $5 \%$ & 167.3 & 325.80 & 313.80 & 175.60 & 354.10 & - & 247.00 & - \\
\hline
\end{tabular}
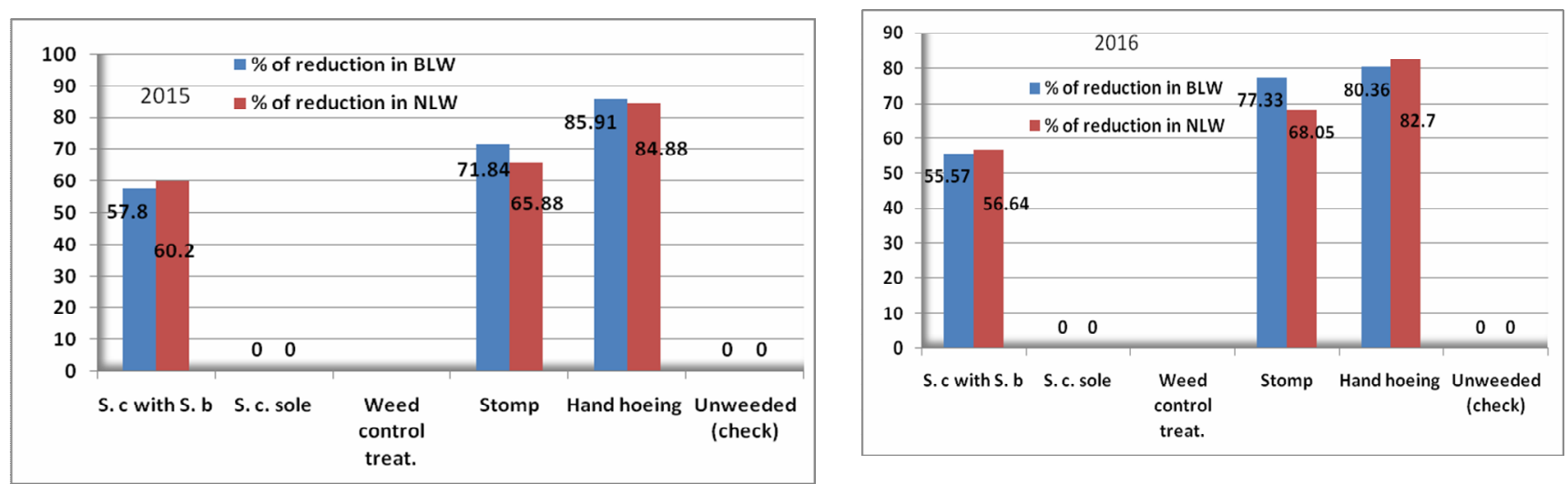

Fig. 1 Effect of intercropping system Sugar cane crop (S. c) with Soy bean crop (S. b) and weed control treatments on $\%$ of reduction in fresh weight of broadleaved (BLW) and narrow leaved weeds (NLW) at 75 DAP in 2015/16 and 2016/17 seasons.

\section{2-Interaction between intercrop- ping and weed control treat- ments:}

Data in Table 2 mention that the interaction between intercropping and weed control treatments were significantly reduction fresh weight of grassy, broad leaved and total weeds in both seasons than sole sugarcane and without weed control treatment. The highest re- duction of grassy and total weeds in 2015/16 and 2016/17 seasons and broad-leaved weeds in 2015/16 season were resulted from sole sugarcane with hand hoeing twice followed by intercropping soybean with hand hoeing, intercropping with Stomp, sugarcane sole with Stomp and intercropping soybean accompanied without weed control treatment, but the 
highest fresh weight of weeds at 75 DAP was resulted from sowing sugarcane sole accompanied without weed control treatment. These results due to hand hoeing treatments was more effective under sole sugarcane thane intercropping soybean with sugarcane due to narrowing space between plants crops, but Stomp was more effective with intercropping soybean and sugarcane than sole sugarcane due to Stomp selective herbicide and sowing soybean intercropping with sugarcane increased crops competition than weeds due to narrowing space between plants/unit and the development growth of plant crops with long time cycle live after planting. These results agreed with those obtained by ElShafai et al., (2010), Singh et al., (2014) and Webber et al.,(2016).

Table 2. Interaction effect between intercropping and weed control treatments on fresh weight $\left(\mathrm{g} / \mathrm{m}^{2}\right)$ of weeds at 75 DAP in $2015 / 16$ and $2016 / 17$ seasons.

\begin{tabular}{|c|c|c|c|c|c|c|c|c|c|}
\hline \multirow{3}{*}{$\begin{array}{c}\text { Intercropping } \\
\text { systems }\end{array}$} & \multirow{3}{*}{ Treats } & \multicolumn{4}{|c|}{ Fresh weight $\left(\mathrm{g} / \mathrm{m}^{2}\right)$} & \multicolumn{4}{|c|}{ Fresh weight of total weeds $\left(\mathrm{g} / \mathrm{m}^{2}\right)$} \\
\hline & & \multicolumn{2}{|c|}{$\begin{array}{l}\text { broad-leaved } \\
\text { weeds }\end{array}$} & \multicolumn{2}{|c|}{ grassy weeds } & \multirow{2}{*}{$\begin{array}{c}\begin{array}{c}\text { Weight } \\
\text { (g) }\end{array} \\
2015 / 16\end{array}$} & \multirow{2}{*}{$\begin{array}{c}\text { Reduction\% } \\
2016 / 17\end{array}$} & \multirow{2}{*}{$\begin{array}{c}\begin{array}{c}\text { Weight } \\
\text { (g) }\end{array} \\
2015 / 16\end{array}$} & \multirow{2}{*}{$\begin{array}{c}\text { Reduction\% } \\
2016 / 17\end{array}$} \\
\hline & & $2015 / 16$ & 2016/17 & 2015/16 & 2016/17 & & & & \\
\hline \multirow{3}{*}{$\begin{array}{c}\text { Sugar cane }+ \\
\text { Soybean }\end{array}$} & Stomp & 282.86 & 406.11 & 330.49 & 298.54 & 613.35 & 85.24 & 704.65 & 84.35 \\
\hline & $\begin{array}{l}\text { Hand hoe- } \\
\text { ing twice }\end{array}$ & 287.63 & 341.88 & 220.39 & 213.66 & 508.02 & 87.78 & 555.54 & 87.66 \\
\hline & $\begin{array}{l}\text { Unweeded } \\
\text { check }\end{array}$ & 541.46 & 903.01 & 550.90 & 447.68 & 1092.36 & 73.71 & 1350.68 & 70.01 \\
\hline \multirow{3}{*}{$\begin{array}{l}\text { Sugar cane } \\
\text { sole }\end{array}$} & Stomp & 458.99 & 500.89 & 561.28 & 380.85 & 1020.27 & 75.45 & 881.74 & 80.42 \\
\hline & $\begin{array}{l}\text { Hand hoe- } \\
\text { ing twice }\end{array}$ & 83.57 & 390.24 & 174.76 & 154.32 & 258.33 & 93.78 & 544.56 & 87.91 \\
\hline & $\begin{array}{l}\text { Unweeded } \\
\text { check }\end{array}$ & 2092.65 & 2824.75 & 2062.48 & 1678.80 & 4155.13 & 0.00 & 4503.55 & 0.00 \\
\hline \multicolumn{2}{|c|}{ L. S. D. at $5 \%$} & 236.50 & 460.70 & 443.80 & 248.30 & 500.80 & & 349.30 & \\
\hline
\end{tabular}

\section{B - Effect of intercropping and weed control treatments on: \\ 1-Yield and yield components}

Data in Table 3 show that the intercropping soybean with sugarcane development of some sugarcane characterestics, compared to sole sugarcane. The intercropping soybean with sugarcane caused significantly increased in stalk length and number of millable cane in 2015/16 season, but this increased was not significantly in 2016/17 season. The increased in stalk diameter $(\mathrm{cm})$ and number of internodes/stalk was not significantly in both seasons. These results due to improvement soil characters by residual of soybean crop due to increased nitrogen element which fixed by soybean legume crop and decreased weed/sugarcane competition due to decreased weed biomass/unit area.

Data in Table 3 reported that hand hoeing twice produced the highest stalk length, number of stalk/fed., stalk diameters and number of internodes/stalk followed by Stomp at the rate $1.75 \mathrm{l} / \mathrm{fed}$. in both seasons, but unweeded check resulted the lowest stalk length and diameters, number of stalk/fed and number of internodes/stalk. These results due to decreased sugarcane/weed competition due to weed control treatments which caused killed weeds and decreased 
fresh weight of weeds. These results

by Bahadar et al. (2004).

were in agreement with those stated

Table 3. Effect of intercropping and weed control treatments on growth characters of sugar can in 2015/16 and 2016/17 seasons.

\begin{tabular}{|c|c|c|c|c|c|c|c|c|}
\hline \multirow[t]{2}{*}{ Treats } & \multicolumn{2}{|c|}{$\begin{array}{l}\text { Stalk length } \\
(\mathrm{cm})\end{array}$} & \multicolumn{2}{|c|}{$\begin{array}{l}\text { Number of milla- } \\
\text { ble cane/fed }\end{array}$} & \multicolumn{2}{|c|}{$\begin{array}{l}\text { Stalk diameters } \\
(\mathbf{c m})\end{array}$} & \multicolumn{2}{|c|}{$\begin{array}{c}\text { Number of inter- } \\
\text { nodes/stalk }\end{array}$} \\
\hline & 2015/16 & 2016/17 & $2015 / 16$ & 2016/17 & 2015/16 & 2016/17 & $2015 / 16$ & 2016/17 \\
\hline \multicolumn{9}{|c|}{ Intercropping system treatment } \\
\hline $\begin{array}{l}\text { sugar cane }+ \text { soy- } \\
\text { bean }\end{array}$ & 2.87 & 3.03 & 57100 & 50100 & 2.52 & 2.06 & 20.08 & 20.75 \\
\hline Sugar cane sole & 2.79 & 3.05 & 51900 & 49517 & 2.35 & 2.06 & 19.33 & 20.75 \\
\hline F test. at 5\% & $*$ & - & $*$ & - & - & - & - & - \\
\hline \multicolumn{9}{|c|}{ Weed control treatments } \\
\hline Stomp & 2.88 & 3.06 & 57600 & 49850 & 2.51 & 2.06 & 19.88 & 20.63 \\
\hline Hand hoeing twice & 2.92 & 3.18 & 60600 & 51850 & 2.58 & 2.13 & 20.75 & 21.88 \\
\hline Unweeded check & 2.69 & 2.89 & 45300 & 47725 & 2.22 & 1.99 & 18.50 & 19.75 \\
\hline L. S. D. at $5 \%$ & 0.049 & 0.114 & 7746 & 2712 & 0.176 & - & 1.66 & 1.31 \\
\hline
\end{tabular}

\section{2-Interaction between intercropping} and weed control treatments:

The interaction between intercropping soybean with sugarcane and weed control had a significant effect on number of stalks/fed in both seasons, as well as stalk length $(\mathrm{m})$, stalk diameter $(\mathrm{cm})$ and number of internodes/stalk in $2015 / 16$ season only, compared to sole sugarcane and without weed control treatments (Table 4). The greatest stalk length, number of stalks/fed. stalk diameters and number of internodes/stalk was resulted from sole sugarcane with hand hoeing, followed by intercropping soybean with hand hoeing twice, but sole sugarcane and without weed control treatment was the lowest on in these traits. These results may be due to decreased sugarcane/weeds competition and improved soil characters by soybean legume crops in intercropping treatments. These results are in agreement with those obtained by (Singh et al., 2014).

Table 4. Interaction effect between intercropping and weed control treatments growth characters of sugar can in 2015/16 and 2016/17 seasons.

\begin{tabular}{|c|c|c|c|c|c|c|c|c|c|}
\hline \multirow[t]{2}{*}{$\begin{array}{l}\text { Intercropping } \\
\text { systems }\end{array}$} & \multirow{2}{*}{$\begin{array}{l}\text { Weed control } \\
\text { treatments }\end{array}$} & \multicolumn{2}{|c|}{$\begin{array}{l}\text { Stalk length } \\
\text { (m) }\end{array}$} & \multicolumn{2}{|c|}{$\begin{array}{l}\text { Number of } \\
\text { millable cane }\end{array}$} & \multicolumn{2}{|c|}{$\begin{array}{c}\text { Stalk } \\
\text { diameters } \\
(\mathbf{c m}) \\
\end{array}$} & \multicolumn{2}{|c|}{$\begin{array}{l}\text { Number of } \\
\text { inter- } \\
\text { nodes/stalk }\end{array}$} \\
\hline & & $2015 / 16$ & 2016/17 & & & $2015 / 16$ & 2016/17 & $2015 / 16$ & 2016/17 \\
\hline \multirow{3}{*}{$\begin{array}{l}\text { Sugar cane } \\
+ \text { Soybean }\end{array}$} & Stomp & & & & & 2.51 & 2.0 & & 20.75 \\
\hline & Hand hos & 2.90 & & & & 2.56 & 2. & 50 & 21.25 \\
\hline & Unweed & 2.8 & & & & 2.48 & & 19.50 & 20.25 \\
\hline \multirow{3}{*}{ Sugar cane sole } & Stomp & 2.87 & & & & 2.52 & 2.05 & 19.50 & 20.50 \\
\hline & Hand hoeing twice & 2.95 & 3.26 & 621 & & 2.59 & 2.15 & 21.00 & 22.50 \\
\hline & Unw & 2.54 & 2.85 & 36600 & 46250 & 1.95 & 1.98 & 17.50 & 19.25 \\
\hline \multicolumn{2}{|l|}{ L. S. D. at $5 \%$} & $*$ & & $*$ & $*$ & $*$ & - & $*$ & - \\
\hline
\end{tabular}

Data in Table 5 pointed out that the effect of intercropping and weed control treatments on yields of sugarcane. The results reported that intercropping soybean with sugarcane increased significantly cane yield (ton/fed) in 2015/16 season only, but this increase was did not significantly on top yield (ton/fed) and sugar yield (ton/fed) in both seasons., compared to sole sugarcane. Intercropping soybean with sugarcane caused 1.17 and $0.66 \%$ increase in cane yield ton/fed., than sugarcane sole in 2015/16 and 2016/17 seasons, respectively. This is too expected since that same treat was observed not record to 
nodes of stalks/fed. The integrated weed management technologies involving the time tested cultural practices, competitive crop cultivars, mulches, cover crops, intercrops with allopathic potential, crop diversification, planting geometry, effi- cient nutrient, water management, etc. along with limited and site-specific herbicide application, that helps in managing weeds through retention of crop, (Singh et al., 2014).

Table 5. Effect of intercropping and weed control treatments on cane and sugar yields in 2015/16 and 2016/17 seasons.

\begin{tabular}{|c|c|c|c|c|c|c|c|c|}
\hline \multirow{3}{*}{ Treats } & \multicolumn{4}{|c|}{ Net cane yield (ton/fed) } & \multirow{2}{*}{\multicolumn{2}{|c|}{$\begin{array}{l}\text { Net top yield } \\
\text { (ton/fed) }\end{array}$}} & \multirow{2}{*}{\multicolumn{2}{|c|}{$\begin{array}{l}\text { Sugar yield } \\
\text { (ton/fed.) }\end{array}$}} \\
\hline & $\begin{array}{c}\text { Yield } \\
\text { ton/fed }\end{array}$ & $\begin{array}{c}\text { Increased } \\
\%\end{array}$ & \multirow{2}{*}{\multicolumn{2}{|c|}{$\begin{array}{c}\text { Yield ton/fed } \\
2016 / 17 \\
\end{array}$}} & & & & \\
\hline & \multicolumn{2}{|c|}{$2015 / 16$} & & & $2015 / 16$ & $2016 / 17$ & $2015 / 16$ & $2016 / 17$ \\
\hline \multicolumn{9}{|c|}{ Intercropping system treatment } \\
\hline Intercropping & 49.91 & 1.17 & 50.56 & 0.66 & 6.79 & 8.82 & 5.21 & 6.32 \\
\hline Sugar cane sole & 49.33 & 0.00 & 50.23 & 0.00 & 6.26 & 8.86 & 5.35 & 6.07 \\
\hline F test. at $5 \%$ & $* *$ & & - & & - & - & - & - \\
\hline \multicolumn{9}{|c|}{ Weed control treatments } \\
\hline Stomp & 49.73 & 3.30 & 50.84 & 4.72 & 6.49 & 9.10 & 5.16 & 6.27 \\
\hline Hand hoeing twice & 51.00 & 5.94 & 51.80 & 6.68 & 7.99 & 9.72 & 5.69 & 6.59 \\
\hline Unweeded check & 48.14 & 0.00 & 48.55 & 0.00 & 5.10 & 7.71 & 4.97 & 5.73 \\
\hline L. S. D. at $5 \%$ & 1.35 & & 1.50 & & 1.15 & 1.38 & 0.39 & 0.42 \\
\hline
\end{tabular}

Concern data in Table 5 show that the effect of weed control treatments under study was significantly effect in cane, top yield and sugar yield (ton/fed), compared to unweeded check in both seasons. Hand hoeing twice gives the highest cane, top and sugar yields (ton/fed) followed by Stomp, but the lowest cane, top and sugar yields (ton/fed) was resulted from unweeded check. This increase due to decreased sugarcane/weed competition by killed weeds and improve growth characters of sugarcane. These results were agreed with that obtained by (Bahadar et al., 2004).

Furthermore, the illustrated data in Tale 6 show that the interaction between intercropping soybean with sugarcane and weed control treatments an caused increase in cane, top and sugar yield (ton/fed) of sugarcane than sole sugarcane and without weed control treatments, but this increased was not significantly in both seasons, except sugar yield (ton/fed.) in 2015/16 season was statistical significantly, compared to sole sugarcane and without weed control. These results due to decreased weeds biomass and increased available fertilizer elements by residual of soybean legume crop in the soil, which conflicted on improved sugarcane plant growth characters and increased sugarcane yields. These results are in harmony with that obtained by (Singh et al., 2014). 
Table 6. Interaction effect between intercropping and weed control treatments on sugar cans yields in $2015 / 16$ and $2016 / 17$ seasons.

\begin{tabular}{|c|c|c|c|c|c|c|c|}
\hline \multirow{3}{*}{$\begin{array}{c}\text { Intercropping } \\
\text { systems }\end{array}$} & \multirow{3}{*}{$\begin{array}{l}\text { Weed control } \\
\text { treatments }\end{array}$} & \multicolumn{2}{|c|}{$\begin{array}{c}\text { Net cane yield } \\
\text { (ton/fed) }\end{array}$} & \multirow{2}{*}{\multicolumn{2}{|c|}{$\begin{array}{l}\text { Net top yield } \\
\text { (ton/fed) }\end{array}$}} & \multirow{2}{*}{\multicolumn{2}{|c|}{$\begin{array}{c}\text { Sugar yield } \\
\text { (ton/fed.) }\end{array}$}} \\
\hline & & Yield & Yield & & & & \\
\hline & & $2015 / 16$ & $2016 / 17$ & $2015 / 16$ & 2016/17 & 2015/16 & 2016/17 \\
\hline \multirow{3}{*}{$\begin{array}{c}\text { Sugar cane }+ \\
\text { Soybean }\end{array}$} & Stomp & 49.99 & 50.90 & 6.75 & 9.18 & 5.12 & 6.46 \\
\hline & Hand hoeing twice & 50.20 & 51.20 & 7.65 & 9.33 & 5.36 & 6.50 \\
\hline & Unweeded check & 49.05 & 49.59 & 5.97 & 7.94 & 5.14 & 6.00 \\
\hline \multirow{3}{*}{$\begin{array}{l}\text { Sugar cane } \\
\text { sole }\end{array}$} & Stomp & 49.48 & 50.78 & 6.23 & 9.01 & 5.20 & 6.10 \\
\hline & Hand hoeing twice & 51.29 & 52.40 & 8.32 & 10.11 & 6.03 & 6.69 \\
\hline & Unweeded check & 47.24 & 47.50 & 4.23 & 7.49 & 4.81 & 5.46 \\
\hline \multicolumn{2}{|l|}{ L. S. D. at $5 \%$} & - & - & - & - & 0.55 & - \\
\hline
\end{tabular}

\section{Conclusion}

This study produced useful information's about some effective weed control treatments hand hoeing twice at 25 and 45 days after planting or Stomp at the rate $1.75 \mathrm{l} / \mathrm{fed}$. intercropped with soybean which was better intercropping option with the advantage of shorter duration which mowing before active tiller stage of sugarcane with ability of soybean legume crops to fix atmospheric nitrogen which enhancing its growth and productivity of sugarcane, additional filled gap of the green feed production in summer season.

\section{References}

Bahadar, K.; M., Jama and H. Azim (2004). Effect of weeds on cane yield and content of sugar cane Pak. J., Weed Sci. Res. 10 (1- 2): 47-50.

El-Shafai, A.M.A.; A.A.O. Fakkar and M.A. Bekheet (2010). Effect of row spacing and some weed control treatments on growth, quality and yield of sugarcane. International J. of Academic Researsh. Vol. (2). No.(4):297-305.

Fakkar, A.A.O.; A.M. Abd-elkareem and A.M.K. Ali (2017). Application times and some weeding control treatments on growth, quality and yield of sugarcane. Egypt. J. of Appl. Sci., 32 (10):228 -242.

Griffin J.L.; C.A. Jones (2004). Red morningglory (Ipomoea coccinea) control with 2,4-D and alternative herbicides. Weed Technol. 18: 3844.

Griffin, L.J. (2009). Efficacy and economics of summer fallow conventional and reduced-Tillage Programs for Sugarcane. Weed Tech. 23(2): 274-279.

Jackson, M.L. (1973). Soil chemical analysis prentice-Hall. Inc. Englewood Clif., N, I. Library Congress, U.S.A.

Kuva, M.A.; R. Gravena, R; Pitelli, R.A; P.J. Christoffoleti and P.L.C., A. Alves (2003). Interference periods of weeds in the sugarcane crop. III -Brachiaria decumbens and Panicum maximum. Planta Daninha; 21 (1):37-44.

Mahendranan, S. and R., Kulanthaivelu (2003). Effect of intercropping, geometry and weed management practices on growth and yield of sugarcane. Souvenir: $65^{\text {th }}$ Annual Convention of the Sugar Technologists' Association of India, Bhubaneshwar, Orissa, India, 2224 August; 68-79.

McIntyre, GE.(1991). Weeds of sugarcane in Mauritius: their description and control. Kin Keong Printing, Singapore.

Meade, G.P. and T.C.J. Chen (1977). Cane sugar hand book. $10^{\text {th }} \mathrm{A}$ Wiley Inter. Sci. publication, John 
Wiley \& Sons, New York, London, Sudney.

Mekky, M.S. (1998). Effect of some agricultural practices on growth, yield and its components of some maize varieties (Zea mayse L). Ph.D. thesis, Fac. of Agric. El Mnia Univ., Egpt, pp. 160.

Mekky, M.S.; M.R. Moshtohry and M.F.A. Dai (2007). The effect of seedbed preparation, intercropping and weed control treatments on sunflower productivity and associated weeds. J. Agric. Sci. Mansoura Univ., 32 (7): 5101-5115.

Sarhan, G.M.A.; A.A. Mahmoud and M.S. Mekky (2003). A comparative study of weed control by covering crop, herbicide and hand hoeing on maize (Zea mays L), guar (Cyamopsis tetragonoloba $\mathrm{L}$.) productivity and associated weeds. Egypt J. Appl. Sci.; 18: $574-585$.

Singh, V.P.; K.K. Barman; R. Singh and A.R. Sharma (2014). Weed Management in Conservation Agriculture Systems. Directorate of Weed Science Research, 482004, Jabalpur, India.

Srikanth, J.; K.P. Salin; S. Easwaramoorthy and C. Kailasam
(2002). Incidence of sugarcane shoot borer under different levels of weed competition, crop geometry, intercropping and nutrient supply systems. Sugar Tech., Volume 4, Issue 3, pp 149 -152.

Steel, R.G.D. and J.H. Torrie (1980). Principles and procedures of statistics. Mc Graw - Hill Book co. Ine., New York, $481 \mathrm{pp}$.

Swanton, C.J. and S.F. Weise (1991). Integrated weed management: rationale and approach. Weed Technology 5: 657- 663 .

Webber, C.L.(2016). Kenaf (Hibiscus cannabinus) and cowpea (Vigna unguiculata) as sugarcane cover crops. J. of Agri. Sci. (Toronto); 8(8):13-20.

Yadav, R.L. and R.K., Sharma (1980). Effect of nitrogen levels and harvesting dates on quality characters and yield of four sugarcane genotypes. Indian J. Agric. Sci., 50581.

Yirefu, F.; Tana, T.; Tafesse, A. and Y. Zekarias (2013). Weed Interference in the sugarcane (Saccharum officinarum L.) plantations of Ethiopia. Agric, Forestry and Fisheries; 2 (6): 239-247. 
التكامل بين زراعة محصول التظطية ومعاملات مكافحة الحشائش علي الحشائش و إنتاج محصول قصب السكر

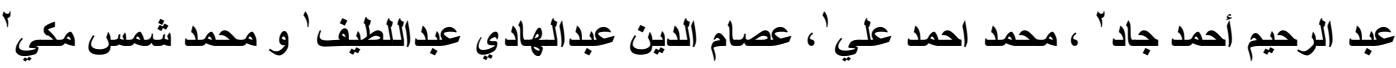

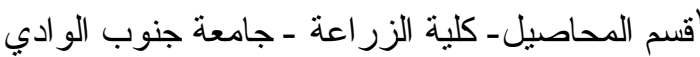

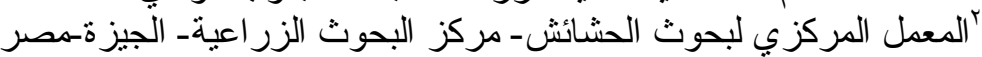

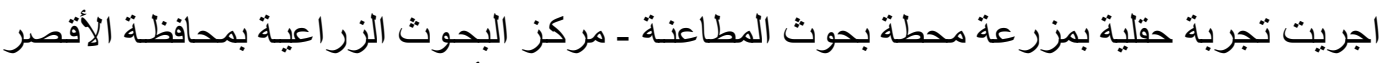

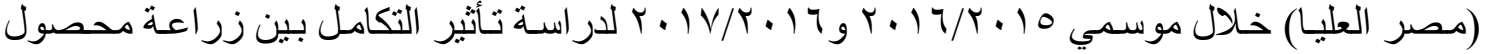

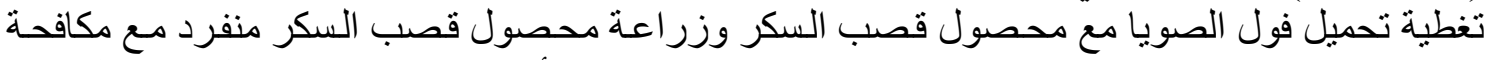

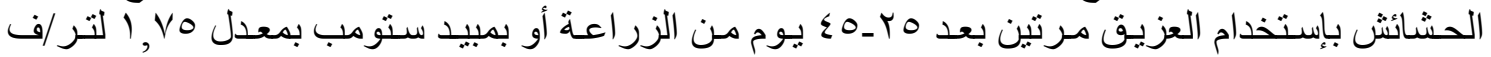

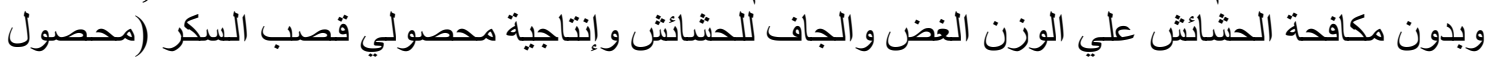

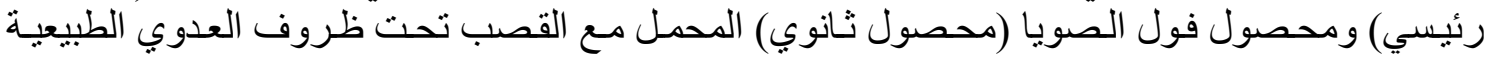

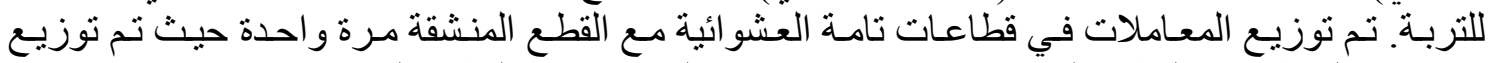

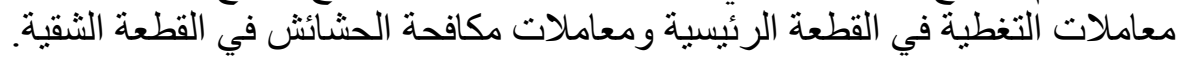

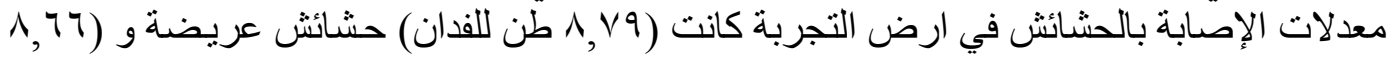

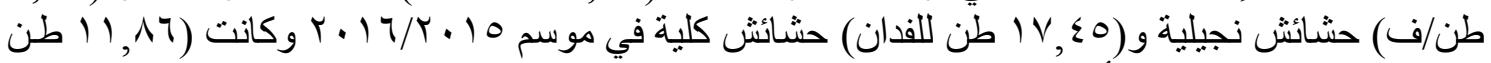

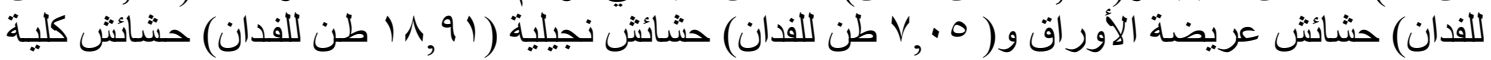

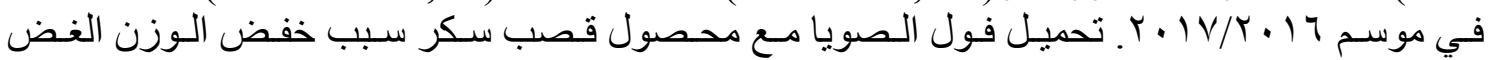

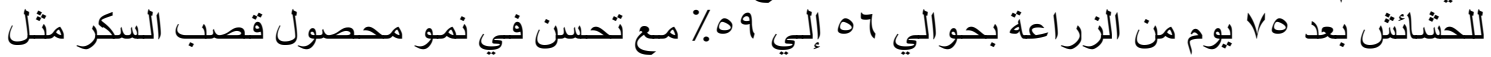
طول وسمك الساق عدد عيدان القصب بالفدان وانعكس ذلك علي إنتاجية محصول القصب ومحت فحصول السكر (طن/فدان) في الموسمين.

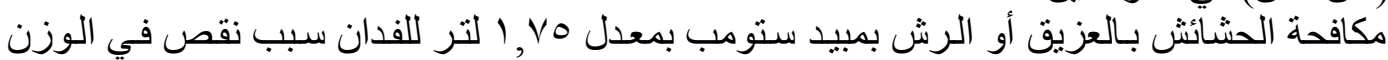

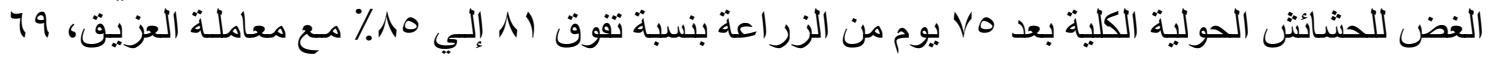

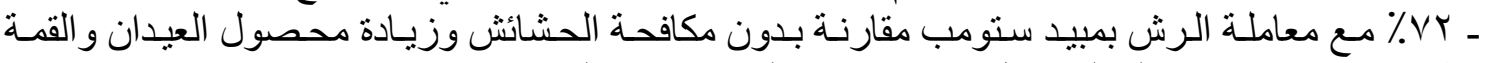

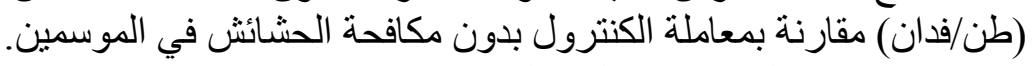

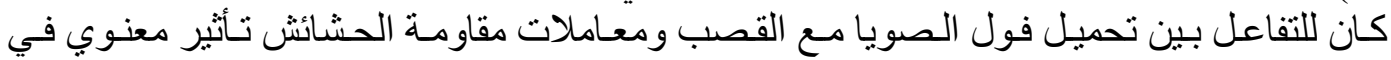

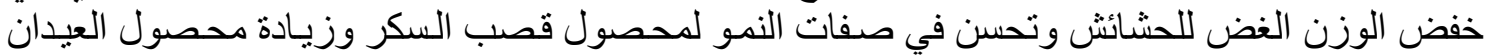

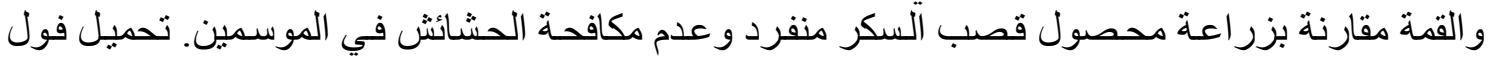

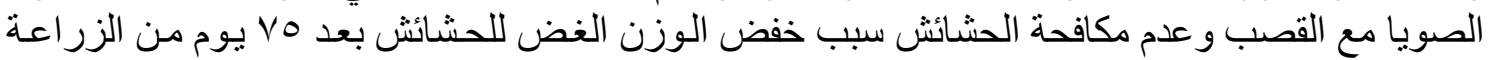

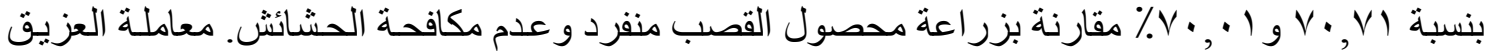

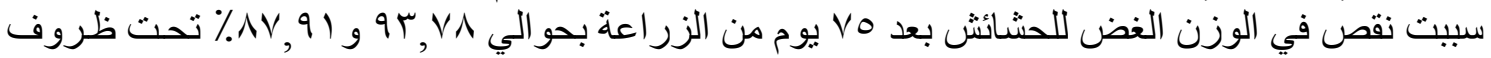

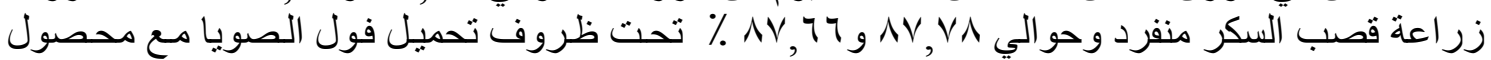

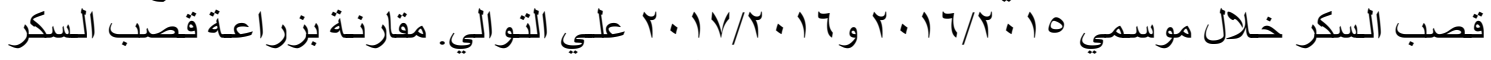

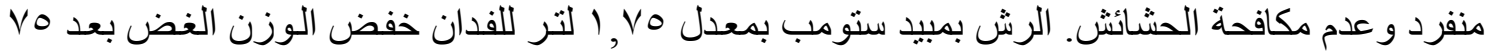

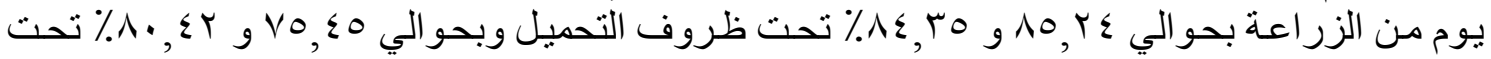

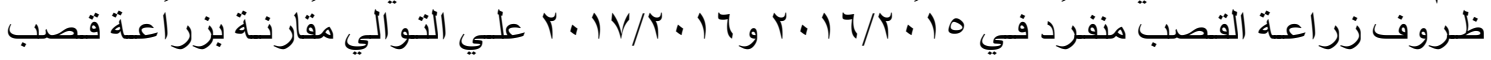

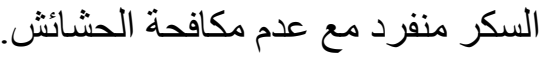

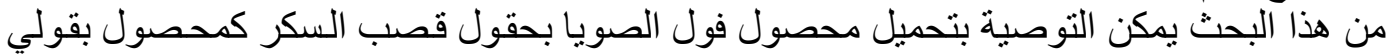

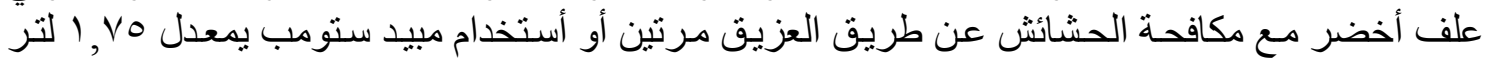

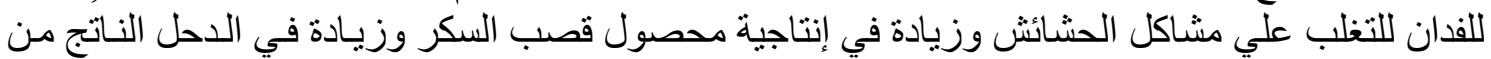
المحصول الثانوي (فول الصويا كمحصول علف أخضر). 